\title{
Minireview
}

\section{Methane Emission from Paddy Fields and its Mitigation Options on a Field Scale}

\author{
KAZUNORI MINAMIKAWA ${ }^{1 *}$, NAOKI SAKAI ${ }^{2}$ and KAZUYUKI YAGI ${ }^{1}$ \\ ${ }^{1}$ National Institute for Agro-Environmental Sciences, 3-1-3 Kannondai, Tsukuba, Ibaraki 305-8604, Japan \\ ${ }^{2}$ Graduate School of Life and Environmental Sciences, University of Tsukuba, 1-1-1 Tennoudai, Tsukuba, \\ Ibaraki 305-8572, Japan
}

(Received April 3, 2006-Accepted July 31, 2006)

Rice is one of the most important cereals, especially in Asian countries. Methane $\left(\mathrm{CH}_{4}\right)$, one of the major greenhouse gases, is emitted from flooded paddy fields as a result of phenomena on various scales. This paper review studies on $\mathrm{CH}_{4}$ emission from paddy fields, paying special attention to mitigation options from the viewpoint of their feasibility on a field scale. Field management of rice paddies is primarily carried out to obtain suitable rice yields, but it also has physical, chemical, and biological effects on $\mathrm{CH}_{4}$ emission. Therefore, some management practices can be win-win options that sustain rice yield and mitigate $\mathrm{CH}_{4}$ emission. For example, appropriate water management for rice growth and yield is also effective in decreasing $\mathrm{CH}_{4}$ emission. Other practices, such as nitrogen fertilizer application and organic matter application can also have positive effects on rice yield and $\mathrm{CH}_{4}$ emission. Recent microbial studies have been revealing the ecology of methanogens and methanotrophs in paddy soils. Further studies on a microbial scale will offer additional clues to the mitigation of $\mathrm{CH}_{4}$ emission from paddy fields.

Key words: methane, global warming, paddy field, rice, field management

\section{Introduction}

Agriculture is essential for food and fiber production, but these activities impact the environment. Rice is one of the world's most important cereals; in 2000 it supplied $20 \%$ of the total calorie intake by humans worldwide ${ }^{58)}$. In Asia, an area of $136 \times 10^{6}$ ha is harvested to produce $556 \mathrm{Tg}(\mathrm{Mt})$ of rough rice, accounting for 88 and $90 \%$ of the world's total, respectively, in 2004 ${ }^{35}$.

In accordance with the availability of water, rice cultivation areas in 2001 could be divided into irrigated $(57 \%$ of the total area in Asia), rainfed lowland (33\%), upland (7\%), and deepwater $(3 \%)^{35)}$. Rice is cultivated sustainably in

\footnotetext{
* Corresponding author; E-mail: minakazu@affrc.go.jp, Tel \& Fax: +81-29-838-8231
}

flooded paddy fields because the reductive conditions cause substances harmful to rice growth to flow out. This is not the case in upland fields.

However, soil reductive conditions cause the emission of methane $\left(\mathrm{CH}_{4}\right)$, one of the major greenhouse gases (GHGs). Paddy fields will continue to be major sources of $\mathrm{CH}_{4}$ because of the need to increase rice production and the harvested area to feed the increasing human population, especially in Asian countries (Fig. 1).

\section{Global Warming \\ Contribution of GHGs}

Global warming is a representative environmental problem that involves all living things on Earth. Carbon dioxide $\left(\mathrm{CO}_{2}\right), \mathrm{CH}_{4}$, and nitrous oxide $\left(\mathrm{N}_{2} \mathrm{O}\right)$ are the major GHGs, 


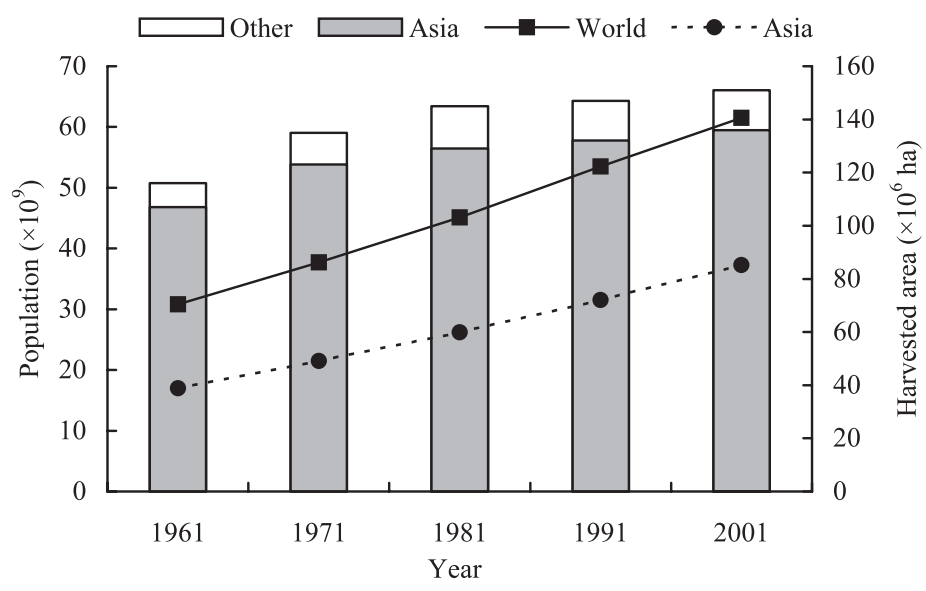

Fig. 1. Decadal changes in human population (line) and rice harvested area (bar) in Asia and the world from 1961 to 2001 (data from FAO ${ }^{35)}$ ).

and radiative forcing of each of these accounts for approximately 60,20 , and $6 \%$, respectively, of the total quantity of direct $\mathrm{GHGs}^{57}$. Each GHG has its own lifetime against tropospheric $\mathrm{OH}$ loss, so time scale must be considered in the global warming potentials (GWPs) for different time horizons, i.e. 20, 100, or 500 years ${ }^{57}$.

Before the Industrial Revolution in the 18th Century, atmospheric concentrations of the three GHGs had been stable because there was only natural exchange ${ }^{56)}$. Anthropogenic GHG emissions have been increasing since the Industrial Revolution, echoing the increasing pace of global agriculture and industrial development ${ }^{57}$. Cole et al. ${ }^{26)}$ reported that $\mathrm{CO}_{2}, \mathrm{CH}_{4}$, and $\mathrm{N}_{2} \mathrm{O}$ emissions from agriculture and agriculture-related land account for $34 \%$ of the annual increase in radiative forcing of these three GHGs. The IPCC ${ }^{57)}$ predicts that the atmospheric concentrations of the three GHGs over the next century will likely be driven by changes in both anthropogenic and natural sources. In taking a precautionary approach to global warming, we must mitigate anthropogenic GHG emissions.

\section{Distribution of $\mathrm{CH}_{4}$ sources}

Methane, especially that emitted from agriculture and agriculture-related lands, is the second-most important GHG (Table 1). The global $\mathrm{CH}_{4}$ emission from the most important sources is estimated at approximately $600 \mathrm{Tg} \mathrm{CH}_{4} / \mathrm{yr}^{57}$. Although the major sources have probably been identified, source strengths are still unclear because of the difficulty in assessing the global emission from biospheric sources, whose strengths are highly variable in space and time ${ }^{57}$.

Methane sources are divided into biological and non-biological types. Biological sources consist of wetlands, termites, oceans, landfills, ruminants, and paddy fields. Non- biological sources are biomass burning and fossil fuel origins such as hydrates, mining, and transport. Both types comprise anthropogenic and natural emissions. As calculated from Fung et al. ${ }^{38)}$ and Hein et al. ${ }^{49}$, anthropogenic $\mathrm{CH}_{4}$ emission accounts for $60-70 \%$ of total $\mathrm{CH}_{4}$ emission.

\section{$\mathrm{CH}_{4}$ Emission from Paddy Fields}

\section{Estimation of total amount of $\mathrm{CH}_{4}$ emission}

Recent studies have estimated the $\mathrm{CH}_{4}$ emission from paddy fields at $53 \mathrm{Tg} \mathrm{CH}_{4} / \mathrm{yr}^{21)}, 25-54 \mathrm{Tg} \mathrm{CH}_{4} / \mathrm{yr}^{98)}, 33-49$ $\mathrm{Tg} \mathrm{CH}_{4} / \mathrm{yr}^{101)}$, or $25.1 \mathrm{Tg} \mathrm{CH}_{4} / \mathrm{yr}^{145)}$, although studies performed before 1990 gave higher estimates $7,25,50,118)$. The recent estimates of paddy emission account for $4.2-9.0 \%$ of the total global $\mathrm{CH}_{4}$ emission (600 $\mathrm{Tg} \mathrm{CH} \mathrm{CH}_{4} / \mathrm{yr}$ ). Nationalscale estimations have been made in rice-cultivating countries, such as China ${ }^{18,66,114,128,150)}$, India ${ }^{106)}$, Japan ${ }^{139,142)}$, Taiwan $^{148)}$, Thailand ${ }^{142)}$, the Philippines ${ }^{100,101)}$, and the United States ${ }^{101,133}$. Previously, Kumaraswamy et al. $^{74)}$ reviewed $\mathrm{CH}_{4}$ emission from paddy fields, and Le Mer and Roger ${ }^{76}$ reviewed $\mathrm{CH}_{4}$ production, oxidation, emission, and consumption in various soils.

Paddy fields also emit $\mathrm{CO}_{2}$ and $\mathrm{N}_{2} \mathrm{O}$. Tsuruta et al. ${ }^{124)}$ evaluated the contributions of emissions of the three GHGs from Japanese paddy fields to the GWPs with a 100-year time horizon. The $\mathrm{CH}_{4}, \mathrm{CO}_{2}$, and $\mathrm{N}_{2} \mathrm{O}$ emissions accounted for $78.2,16.0$, and $5.8 \%$ of the total $\mathrm{CO}_{2}$-equivalent emission, respectively. Therefore, a decrease in $\mathrm{CH}_{4}$ emission would be the best option for mitigating total GHG emissions from paddy fields.

\section{Mechanism of $\mathrm{CH}_{4}$ emission}

In flooded paddy soils, after the trapped molecular $\mathrm{O}_{2}$ has 
Table 1. Estimates of the global $\mathrm{CH}_{4}$ sources $\left(\mathrm{Tg} \mathrm{CH}_{4} / \mathrm{yr}\right)$ from different references

\begin{tabular}{|c|c|c|c|c|c|c|}
\hline $\begin{array}{l}\text { References: } \\
\text { Base year: }\end{array}$ & $\begin{array}{l}\text { Fung et al. }{ }^{38)} \\
1980 \mathrm{~s}\end{array}$ & $\begin{array}{c}\text { Hein et al. }{ }^{49)} \\
-\end{array}$ & $\begin{array}{c}\text { Lelieveld } \text { et } \text { al. }^{75)} \\
1992\end{array}$ & $\begin{array}{c}\text { Houweling et al. }{ }^{53)} \\
-\end{array}$ & $\begin{array}{c}\text { Mosier et al. }{ }^{98)} \\
1994\end{array}$ & $\begin{array}{c}\text { Olivier et al. }{ }^{105)} \\
1990\end{array}$ \\
\hline \multicolumn{7}{|l|}{ Natural sources } \\
\hline Wetlands & 115 & 237 & $225^{\mathrm{b}}$ & 145 & & \\
\hline Termites & 20 & - & 20 & 20 & & \\
\hline Ocean & 10 & - & 15 & 15 & & \\
\hline Hydrates & 5 & - & 10 & - & & \\
\hline \multicolumn{7}{|l|}{ Anthropogenic sources } \\
\hline Energy & 75 & 97 & 110 & 89 & & 109 \\
\hline Landfills & 40 & 35 & 40 & 73 & & 36 \\
\hline Ruminants & 80 & $90^{\mathrm{a}}$ & 115 & 93 & 80 & $93^{\mathrm{a}}$ \\
\hline Waste treatment & - & a & 25 & - & 14 & a \\
\hline Rice agriculture & 100 & 88 & $\mathrm{~b}$ & - & $25-54$ & 60 \\
\hline Biomass burning & 55 & 40 & 40 & 40 & 34 & 23 \\
\hline Other & - & - & - & 20 & 15 & \\
\hline Total source & 500 & 587 & 600 & & & \\
\hline
\end{tabular}

Data from IPCC ${ }^{57)}$.

—: not estimated, blank: no aim to estimate originally.

${ }^{a}$ Waste treatment included under ruminants.

${ }^{\mathrm{b}}$ Rice agriculture included under wetlands.

quickly been consumed, sequential reduction of the following soil oxidants progresses in accordance with the thermodynamic theory: $\mathrm{NO}_{3}{ }^{-}, \mathrm{Mn}^{4+}, \mathrm{Fe}^{3+}, \mathrm{SO}_{4}{ }^{2-}$, and $\mathrm{CO}_{2}$. Methane is the final product of the reductive process and is produced by methanogens. The major direct substrates for methanogenesis are $\mathrm{H}_{2}+\mathrm{CO}_{2}$, formate, acetate, methyl alcohol, and methylamine. The following two reactions are dominant in methanogenesis in the soil: the reduction of $\mathrm{CO}_{2}$ using $\mathrm{H}_{2}$ and the transmethylation of acetate ${ }^{117,121)}$.

Carbon substrates for methanogenesis are supplied from applied organic matter, exudates and sloughed tissues of rice plants, and soil organic matter ${ }^{68,137)}$. Part of the $\mathrm{CH}_{4}$ produced is consumed by methanotrophs under oxidative conditions in the rhizosphere of rice plants and in a thin layer of soil interfacing with the surface water. Most of the $\mathrm{CH}_{4}$ emitted is transported to the atmosphere through the aerenchyma of rice plants, but other pathways are ebullition and diffusion through surface water ${ }^{17,119)}$. Moreover, a considerable amount of $\mathrm{CH}_{4}$ trapped in the soil is emitted by direct diffusion during drainage ${ }^{90)}$.

Soil redox potential (Eh) is the most useful indicator for measuring soil redox conditions, although there are other indicators such as, the terminal electron-accepting processes and oxidative capacity ${ }^{40}$. Soil Eh is a comprehensive measure of soil chemical and biological redox processes ${ }^{131)}$. With the development of reductive conditions, soil Eh de- creases from positive $(600 \mathrm{mV})$ to negative $(<-200 \mathrm{mV})$. Generally, $\mathrm{CH}_{4}$ production begins at approximately -150 $\mathrm{mV}$, and is stimulated at less than $-200 \mathrm{mV}^{84,130}$.

\section{Methanogens and methanotrophs}

The significance of soil microorganisms, including methanogens and methanotrophs, as controllers of atmospheric trace gases has been well documented ${ }^{27}$. Methanogens phylogenetically belong to the domain Archaea. In paddy soils, the following seven genera have been isolated or evidenced: Methanobacterium, Methanobrevibacter, Methanoculleus, Methanogenium, Methanosaeta, Methanosarcina, and Methanospirillum ${ }^{5,6,36,63,64,71,87,108)}$. The population of methanogens varies among soils. In Senegal, the population in 29 paddy soils ranged between $10^{2}$ and $10^{7} \mathrm{~g}^{-1}$ dry-soil $1^{41)}$. In an Italian paddy soil, acetotrophs numbered $10^{4} \mathrm{~g}^{-1}$ dry soil and the hydrogenotroph population was $10^{6} \mathrm{~g}^{-1}$ dry soil ${ }^{86}$. Asakawa and Hayano ${ }^{5)}$ reported that the populations of hydrogenotrophs, methylotrophs, and acetotrophs were $10^{3}$ $10^{4}, 10^{4}-10^{5}$, and $10^{4}-10^{5} \mathrm{~g}^{-1}$ dry soil, respectively, in Japanese paddy fields. Moreover, several reports have revealed that the population and community structure of methanogens remain more or less constant regardless of the type of field management $t^{5,36,86)}$.

The $\mathrm{CH}_{4}$-oxidizing bacteria are divided into methanotrophs and autotrophic ammonium-oxidizing bacteria. Methan- 
otrophs isolated from paddy soils belong to the genera Methylocystis ${ }^{122)}$ and Methylosinus ${ }^{15,77)}$. The population of methanotrophs is reported to be $10^{4} \mathrm{~g}^{-1}$ dry soil in Japanese paddy soils ${ }^{136)}$ and $10^{6} \mathrm{~g}^{-1}$ dry soil in Italian paddy soils ${ }^{10)}$. The methanotroph population increased with the growth of rice plants in an Italian paddy soil ${ }^{34,42)}$. On the other hand, Takeda et al. ${ }^{123)}$ reported that the population was $10^{5}-10^{6} \mathrm{~g}^{-1}$ dry-soil in Japanese paddy soil, and that it did not change with irrigation or the kind of fertilizer applied.

\section{Different scales of factors controlling $\mathrm{CH}_{4}$ emission}

Yagi ${ }^{139)}$ categorized the factors controlling $\mathrm{CH}_{4}$ emission into four scales (Fig. 2). From the microbial to global scales, these factors are soil properties, rice plant activity, field management, and climate. The most important objective of studies on $\mathrm{CH}_{4}$ emission from paddy fields is the mitigation of global warming. Of course, it is also essential to balance mitigation options with rice production.

Emitted $\mathrm{CH}_{4}$ affects global warming on the largest scale, but the microbiological processes of $\mathrm{CH}_{4}$ production and oxidation occur on the smallest scale. In terms of environmental factors, temperature $33,37,153)$ and water regime ${ }^{92,110)}$ principally determine the potential for $\mathrm{CH}_{4}$ emission. On the microbial and plant scales, the amount of $\mathrm{CH}_{4}$ emitted is determined by the population and activity of microorganisms ${ }^{1,34,44,48,86)}$, the physical conditions and chemical properties of the soil ${ }^{125,126,135,151,152)}$, the biomass and activity of rice plants ${ }^{22,28)}$, and the kinds and amounts of substrates $^{68,137)}$.

On the other hand, from the farmer's viewpoint, field management on a field scale is the sole way to produce rice and increase the rice yield. Such field management also has physical, chemical, and biological effects on $\mathrm{CH}_{4}$ emission. A statistical analysis by Yan et al. ${ }^{146)}$ showed that the average $\mathrm{CH}_{4}$ flux during the growing period was significantly affected by water management, organic matter application, content of soil organic carbon, soil $\mathrm{pH}$, preseason water status, and climate. Therefore, ecological problems on different scales and from different viewpoints-i.e. $\mathrm{CH}_{4}$ emission (global warming) and rice production-need to be considered simultaneously.

Irrigated paddy fields were estimated to account for 70 $80 \%$ of $\mathrm{CH}_{4}$ emission from the global rice area, whereas rainfed (about 15\%) and deepwater (about 10\%) fields had

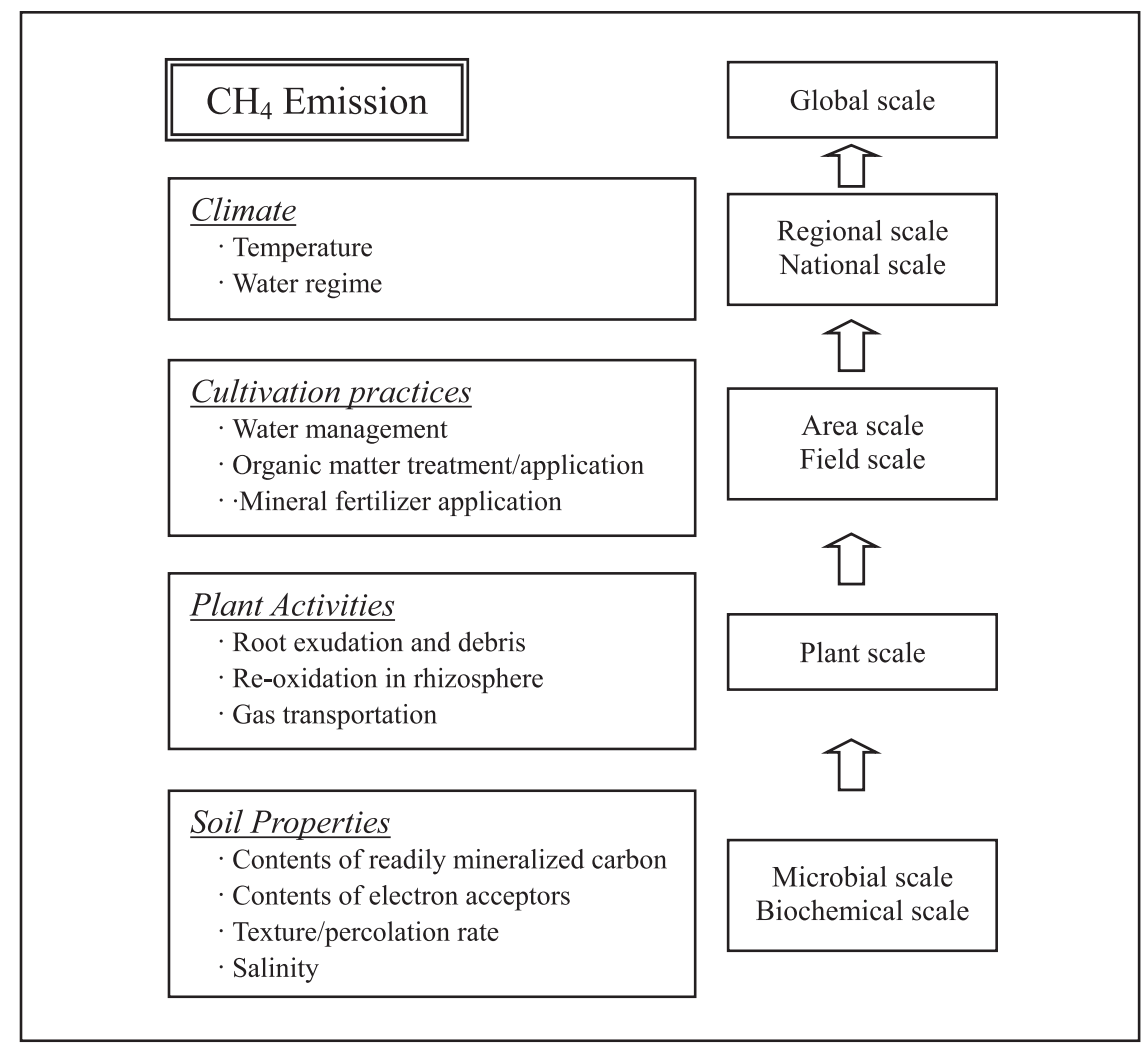

Fig. 2. The factors controlling $\mathrm{CH}_{4}$ emissions from paddy fields on different scales (modified from $\mathrm{Yagi}^{139)}$ ). 
much lower shares ${ }^{133)}$. As evaluated by Wassmann et al. ${ }^{134)}$, irrigated rice offers the most options for modifying field management to mitigate $\mathrm{CH}_{4}$ emission. On the other hand, mitigation options for rainfed and deepwater fields are very limited in both number and potential gains ${ }^{134)}$. Therefore, it is certain that irrigated paddy fields are the most promising targets for applying mitigation options.

\section{Effects of Field Management on $\mathrm{CH}_{4}$ Emission from Paddy Fields}

A combination of appropriate field management techniques is used to obtain suitable rice yields and these techniques have various effects on $\mathrm{CH}_{4}$ emission. Wassmann et $a l .{ }^{132}$ ) reported that local variation in field management among Asian countries overrode the impacts of soil- and climate-related factors on $\mathrm{CH}_{4}$ emission. Yagi ${ }^{140)}$ listed the mitigation options for $\mathrm{CH}_{4}$ emission and evaluated them from the viewpoints of rice productivity and economics (Table 2). Generally, farmers aim to a greater or lesser extent for economic rice production. Although the consideration of environmental issues on various scales has some economic advantages in a few developed countries, the en- vironmental viewpoint is never comparable to the economic one under the present condition.

\section{Water management}

Water management, such as midseason drainage and intermittent irrigation is commonly used in irrigated paddy fields in Japan, to control surplus tillering and to supply rice roots with molecular $\mathrm{O}_{2}$ for preventing sulfide toxicity ${ }^{65)}$. Various countries have adopted similar management practices, but they cannot be applied to rainfed and deepwater fields. Although there remains some vagueness in timing and span, appropriate water management increases rice yield.

Water management is also one of the most effective options in decreasing $\mathrm{CH}_{4}$ emission, because it prevents the development of soil reductive conditions. On a rainfed lowland field, $\mathrm{CH}_{4}$ emission was about 4-10 times higher than that on an irrigated shallow field ${ }^{110}$. One or multiple drainage systems have been reported to decrease $\mathrm{CH}_{4}$ emission compared to continuous flooding under field and lysimeter conditions ${ }^{102,141,156)}$ and microcosm and pot conditions $^{88,92,109)}$. Moreover, many researchers have reported that midseason drainage and/or intermittent irriga-

Table 2. Evaluation of mitigation options for $\mathrm{CH}_{4}$ emission

\begin{tabular}{|c|c|c|c|c|c|c|c|c|}
\hline \multirow{3}{*}{ Field management } & \multirow{3}{*}{$\begin{array}{l}\text { Mitigation } \\
\text { efficiency }\end{array}$} & \multicolumn{7}{|c|}{ Problem for application } \\
\hline & & \multicolumn{2}{|c|}{ Applicability } & \multicolumn{2}{|c|}{ Economy } & \multicolumn{2}{|c|}{ Effects on } & \multirow{2}{*}{ Other effects } \\
\hline & & Irrigated & Rainfed & Cost & Labor & Yield & Fertility & \\
\hline \multicolumn{9}{|l|}{ Water management } \\
\hline Midseason drainage & $\square$ & $\bigcirc$ & 0 & $\sim$ & $\uparrow$ & + & $\sim$ & May promote $\mathrm{N}_{2} \mathrm{O}$ \\
\hline Short flooding & $\square$ & $\bigcirc$ & 0 & $\sim$ & $\sim$ & - & - & May promote $\mathrm{N}_{2} \mathrm{O}$ \\
\hline High percolation & $\square$ & 0 & 0 & $\uparrow$ & $\uparrow$ & + & $\sim$ & May promote nitrate leaching \\
\hline \multicolumn{9}{|l|}{ Soil amendments } \\
\hline Sulfate fertilizer & $\square$ & $\bigcirc$ & $\bigcirc$ & $\uparrow$ & $\sim$ & $\triangle$ & - & May cause $\mathrm{H}_{2} \mathrm{~S}$ injury \\
\hline Oxidants & $\square$ & $\bigcirc$ & $\bigcirc$ & $\uparrow$ & $\uparrow$ & $\triangle$ & - & \\
\hline Soil dressing & $\bigcirc$ & $\bigcirc$ & $\bigcirc$ & $\uparrow$ & $\uparrow$ & - & - & \\
\hline \multicolumn{9}{|l|}{ Organic matter } \\
\hline Composting & $\square$ & $\bigcirc$ & $\bigcirc$ & $\uparrow$ & $\uparrow$ & + & + & \\
\hline Aerobic decomp. & $\square$ & $\bigcirc$ & $\bigcirc$ & $\sim$ & $\uparrow$ & $\sim$ & $\sim$ & \\
\hline Burning & $\bigcirc$ & 0 & $\bigcirc$ & $\sim$ & $\uparrow$ & $\sim$ & $\sim$ & Atmospheric pollution \\
\hline \multicolumn{9}{|l|}{ Others } \\
\hline Deep tillage & $\bigcirc$ & $\bigcirc$ & $\bigcirc$ & $\uparrow$ & $\uparrow$ & - & - & \\
\hline No tillage & $?$ & 0 & 0 & $\sim$ & $\downarrow$ & - & $\sim$ & \\
\hline Rotation & $\bigcirc$ & $\bigcirc$ & $\triangle$ & $\sim$ & $\uparrow$ & - & - & \\
\hline Cultivar & $\bigcirc$ & $\bigcirc$ & 0 & $\sim$ & $\sim$ & $\sim$ & $\sim$ & Require long time \\
\hline
\end{tabular}

Modified from Yagi ${ }^{140}$.

$\square$ : very effective, $\bigcirc$ : Effective/applicable, $\triangle$ : case by case, ous situation, + : positive, - : negative. 


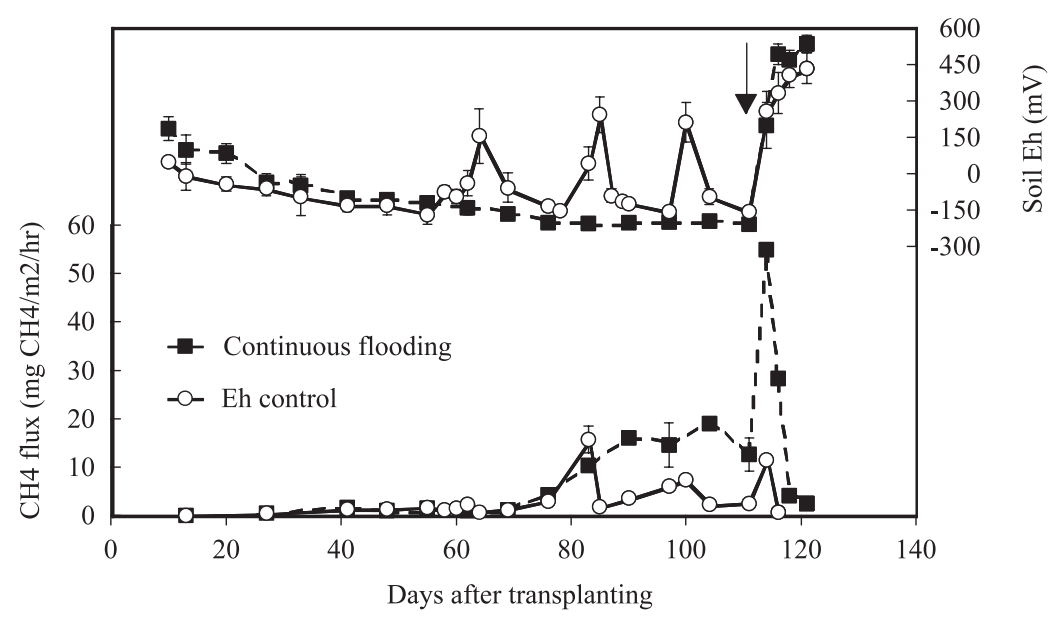

Fig. 3. Seasonal changes in soil Eh (upper lines) and $\mathrm{CH}_{4}$ flux (lower lines) with different water management, continuous flooding and Eh control in an Andosol field with rice straw application (Minamikawa et al. ${ }^{91)}$ ). The upper and lower limits of Eh control are 100 and $-150 \mathrm{mV}$, respectively. Vertical bars indicate the standard error. An arrow indicates the final drainage.

tion decrease $\mathrm{CH}_{4}$ emission without decreasing rice grain yield $^{16,112,127,143)}$.

However, the drainage timing and span of the conventional water management depend on the farmer's empirical knowledge and customary practices, which may lead to careless $\mathrm{CH}_{4}$ emission. Recently, to positively decrease $\mathrm{CH}_{4}$ emission, water management based on soil Eh (Eh control) has been proposed ${ }^{88)}$. Eh control maintains soil Eh between predetermined lower and upper limits by drainage and flooding. Field experiments have demonstrated that Eh control decreases $\mathrm{CH}_{4}$ emission by $64 \%$ compared to continuous flooding without decreasing rice grain yield ${ }^{91)}$ (Fig. 3).

Appropriate water management for sound rice growth is also effective in decreasing $\mathrm{CH}_{4}$ emission. This means that appropriate water management will be a win-win option for increasing rice yield and decreasing $\mathrm{CH}_{4}$ emission. At present, optimizing water management in irrigated paddy fields is the best way to mitigate $\mathrm{CH}_{4}$ emissions from the global rice area. We cannot do better than adopt appropriate water management in consideration of $\mathrm{N}_{2} \mathrm{O}$ emission during drainage ${ }^{16,19,102,144)}$. There is room to improve water management and achieve an optimal balance between rice yield and GHG emissions.

\section{Soil amendment}

Soil amendment is now essential to intensive cultivation. Nitrogen is an element that is fundamental to crops and strongly affects growth and yield. However, the application of large amounts of nitrogen to paddy fields can cause overluxuriant growth, spindly growth, lodging of rice plants, and $\mathrm{N}_{2} \mathrm{O}$ emission ${ }^{19,54)}$. There have been many reports on the ef- fects of the type, rate, and method of nitrogen application on $\mathrm{CH}_{4}$ emission. However, there is little information on the effect of slow- (controlled-) release nitrogen fertilizer.

Sulfate-containing fertilizers are known to decrease $\mathrm{CH}_{4}$ emission because of the competition between sulfate-reducing bacteria and methanogens for the substrates, hydrogen and acetate ${ }^{51,52)}$. Many researchers have demonstrated the $\mathrm{CH}_{4}$-decreasing effect of ammonium sulfate [ $\left.\left(\mathrm{NH}_{4}\right)_{2} \mathrm{SO}_{4}\right]$ under field conditions ${ }^{16,30,67,80,81,82,90,117,149)}$ and pot and incubation conditions ${ }^{9,129)}$. The application of gypsum $\left(\mathrm{CaSO}_{4}\right)$ also decreased $\mathrm{CH}_{4}$ emission ${ }^{29,30)}$. Minamikawa et al. ${ }^{90)}$ reported that increases in the application rate of ammonium sulfate from 45 to $135 \mathrm{~kg} \mathrm{~N} / \mathrm{ha}$ (compared to a conventional rate of $90 \mathrm{~kg} \mathrm{~N} / \mathrm{ha}$ ) decreased $\mathrm{CH}_{4}$ emission and increased rice yield under field conditions (Table 3). Ammonium sulfate is a physiological acid fertilizer and in 2002 accounted for only $2.5 \%$ of the total amount of nitrogen fertilizers consumed globally ${ }^{35}$. Although ammonium sulfate can induce

Table 3. Total $\mathrm{CH}_{4}$ emission and rice yield at different application rates of ammonium sulfate

\begin{tabular}{cccc}
\hline $\begin{array}{c}\text { Application rate } \\
(\mathrm{kg} \mathrm{N} / \mathrm{ha})\end{array}$ & $\begin{array}{c}\mathrm{CH}_{4} \text { emission } \\
\left(\mathrm{g} \mathrm{CH}_{4} / \mathrm{m}^{2}\right)\end{array}$ & $\begin{array}{c}\text { Grain yield } \\
\left(\mathrm{g} \mathrm{DW} / \mathrm{m}^{2}\right)\end{array}$ & $\begin{array}{c}\text { Straw yield } \\
\left(\mathrm{g} \mathrm{DW} / \mathrm{m}^{2}\right)\end{array}$ \\
\hline 135 & $2.67 \mathrm{~b}$ & $682 \mathrm{a}$ & $775 \mathrm{a}$ \\
90 & $6.73 \mathrm{a}$ & $646 \mathrm{a}$ & $693 \mathrm{~b}$ \\
45 & $7.86 \mathrm{a}$ & $514 \mathrm{~b}$ & $494 \mathrm{c}$ \\
0 & Not determined & $389 \mathrm{c}$ & $394 \mathrm{~d}$ \\
\hline
\end{tabular}

Data from Minamikawa et al. ${ }^{90)}$.

The same letters in each column are not significantly different at $p=0.05$ by Tukey's HSD test. 
rice root rot from $\mathrm{H}_{2} \mathrm{~S}$ production, its use is a win-win option.

Urea $\left[\left(\mathrm{NH}_{2}\right)_{2} \mathrm{CO}\right]$ is the most consumed nitrogen fertilizer in the world, accounting for $47.4 \%$ of the total as of $2002^{355}$. The incorporation of urea into the soil at a depth of $20 \mathrm{~cm}$ decreased $\mathrm{CH}_{4}$ emission to half of that with surface application ${ }^{118)}$. Compared to the effects of ammonium sulfate, the effects of urea on $\mathrm{CH}_{4}$ emission are very complex, bringing conflicting results among different fields and soils. Many researchers have reported that $\mathrm{CH}_{4}$ emission increased with increases in the rate of application of urea and/ or was higher than no application under field conditions $^{28,78,79)}$ and pot and incubation

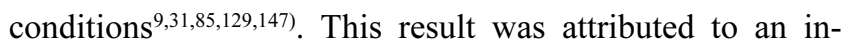
crease in soil $\mathrm{pH}$ caused by the hydrolysis of urea ${ }^{129)}$, an increase in rice biomass ${ }^{9}$, and the inhibition of methanotrophs by ammonium ${ }^{27,31,73)}$. On the other hand, contrasting results have been reported ${ }^{12,13,19,69,89,156)}$. Bodelier et al. ${ }^{12,13)}$ reported that ammonium stimulated the oxidation of $\mathrm{CH}_{4}$ and methanotrophs in a microcosm experiment. Cai and Mosier ${ }^{20)}$ found that if the initial $\mathrm{CH}_{4}$ concentration in the headspace was sufficiently high under soil incubation conditions, then adding ammonium chloride $\left(\mathrm{NH}_{4} \mathrm{Cl}\right)$ first inhibited but eventually stimulated the oxidation of $\mathrm{CH}_{4}$. Therefore, the effect of ammonium on $\mathrm{CH}_{4}$ oxidation may vary among experimental conditions. Schimel ${ }^{116)}$ arranged the effects of ammonium on $\mathrm{CH}_{4}$ oxidation into the following three-scale phenomenon: stimulation with increases in rice biomass on a plant/ecosystem scale; inhibition with population growth of methanotrophs on a microbial-community scale; and stimulation with competition for methane monoxygenase on a biochemical scale. It was concluded that the set of effect that dominates the total $\mathrm{CH}_{4}$ emission may vary among systems $^{116)}$.

The application of agricultural chemicals affects the activity of microorganisms, as reported by Mohanty et al. ${ }^{96)}$ and Satpathy et al. ${ }^{115)}$. However, such chemicals are highly specialized, and their residues in rice plants and soil are minimal or zero if withholding periods for residues are observed. Therefore, the effects of these chemicals on microorganisms are more or less inevitable, and there would be little room to change the rate and kind of chemicals with regard to the emission of $\mathrm{CH}_{4}$.

Soil oxidants are added to degraded paddy fields to avoid the autumn decline (akiochi) of rice growth. Oxidants delay the development of soil reductive conditions. There have been several reports on the effects of $\mathrm{Fe}$-containing materials on decreases in $\mathrm{CH}_{4}$ emission $^{39,61,107,155)}$. Addition of $\mathrm{Fe}-$ containing slag increased the soil Eh and $\mathrm{pH}^{103,155)}$. Yoshiba et al. ${ }^{155)}$ also reported $\mathrm{CH}_{4}$-decreasing effects of $\mathrm{Mn}^{4+}$ and $\mathrm{SO}_{4}{ }^{2-}$. Although excessive use of oxidants would damage the physiology of rice plants, these substances could be used as a mitigation option.

\section{Organic matter management}

The application of organic matter conserves soil fertility for sustainable rice production. In Japan, it is recommended that organic matter be applied together with a chemical fertilizer. Because of the slow release of organic nitrogen during decomposition, the use of organic matter prevents temporal and spatial variations in rice yield. However, the organic matter supplies substrates for the development of soil reductive conditions and $\mathrm{CH}_{4}$ production. The kind, rate, timing, and degree of maturation affect the magnitude of $\mathrm{CH}_{4}$ emission.

In paddy fields, rice straw is a reasonable type of organic matter to apply in terms of the carbon cycle. Many studies have reported that rice straw increases $\mathrm{CH}_{4}$

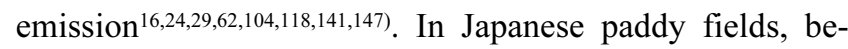
cause of aerobic decomposition during the fallow period, the application of straw in the previous autumn or winter decreased $\mathrm{CH}_{4}$ emission compared to just before transplanting (spring) ${ }^{43,85}$. Moreover, several researchers reported that there was no difference in $\mathrm{CH}_{4}$ emission between winter application (application two-month prior) and no application $^{55,91}$. Composting of rice straw is also effective in decreasing $\mathrm{CH}_{4}$ emission because of aerobic decomposition outside the field ${ }^{24,141)}$. Burned straw also decreases $\mathrm{CH}_{4}$ emissions from fields ${ }^{14)}$, but $\mathrm{CO}_{2}$ emissions are increased by the burning.

There have been reports on other kinds of organic matter, such as wheat straw ${ }^{156)}$, Sesbania rostrata ${ }^{16,30,62,104,110)}$, Azolla caroliniana Wild ${ }^{11)}$ and manures from cow, pig, and

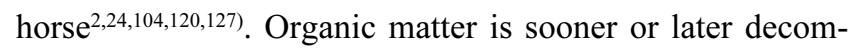
posed to $\mathrm{CO}_{2}$ or $\mathrm{CH}_{4}$, and preferably it should be emitted as $\mathrm{CO}_{2}$ with the lowest GWP by composting, maturation, and aerobic decomposition. The amount of animal manure is likely to increase with increases in the human population, thus increasing GHG emissions. Further studies are needed on the effective treatment of animal manure in ways that do not enhance GHG emissions.

\section{Others}

There is a little information available on the effect of tillage on $\mathrm{CH}_{4}$ emission. In Japan, no/minimum tillage is carried out mainly to reduce the cost and energy consumption in machinery use. It is expected that no/minimum tillage will increase soil resistance and prevent both wet injury and 
the development of soil reductive conditions. Moreover, no/ minimum tillage may be effective in soil carbon sequestration $^{32,45)}$. There have been several reports that no/ minimum tillage decreased $\mathrm{CH}_{4}$ emission compared to conventional tillage $\mathrm{e}^{23,46,59,85,95)}$. On the other hand, several researchers reported the enhancement of $\mathrm{CH}_{4}$ emission with no tillage ${ }^{46,12)}$. This conflicting result can be explained partly by differences in soil characteristics, such as the water requirement in depth ${ }^{59)}$ and a high content of $\mathrm{Fe}^{3+}{ }^{36}$. With no tillage, no straw is applied to the topsoil, and the redox conditions are relatively high ${ }^{85,95)}$. Surface-applied rice straw caused the surface soil to be reductive, and $\mathrm{CH}_{4}$ emission occurred near the surface ${ }^{46,47}$. Although most reports agreed with the decreasing effect of no tillage on $\mathrm{CH}_{4}$ emission in the short term, it is necessary to consider the long-term effects because of the accumulation of rice residues on and in the soil and the changes in soil physical properties.

Rice cultivars are selected to obtain higher yields and better quality. Rice plants play several important roles in $\mathrm{CH}_{4}$ emission, and their large biomass cannot help increasing the emission. Previous reports compared, in addition to $\mathrm{CH}_{4}$ emission, the following characteristics of several cultivars; rice growth and yield ${ }^{8,67,93,127)}$, plant conductance of $\mathrm{CH}_{4}$ transport ${ }^{154)}$, and concentration of dissolved organic carbon in the soil ${ }^{83)}$. However, the development of new cultivars is far removed from farmers. It may be a possible option in the future.

There have been a few reports on the effects of crop rotation $^{72)}$, direct seeding ${ }^{70,97,127)}$, and planting density ${ }^{90,138)}$. Their effects on $\mathrm{CH}_{4}$ emission depend on changes in the soil redox conditions and the physiology of rice plants. There have already been studies on most of the conventional field management techniques used for rice production, but there is room to propose other techniques that positively decrease $\mathrm{CH}_{4}$ emission.

\section{Contributions of Microbial Studies to the Mitigation of $\mathrm{CH}_{4}$ Emission}

Present mitigation options are mostly those on a field scale, which are relatively feasible for farmers. These options basically affect the ecology of microorganisms, but insights into microbial ecology are often apt to be disregarded in field-scale mitigation. How do microbial studies contribute to the mitigation of $\mathrm{CH}_{4}$ emission?

Variations in $\mathrm{CH}_{4}$ emission from paddy fields are attributable mostly to variations in methanotrophic activity ${ }^{11,118)}$, indicating that methanotrophs are suitable organisms for controlling $\mathrm{CH}_{4}$ emission ${ }^{1)}$. Therefore, stimulation of the populations and/or activity of methanotrophs can decrease $\mathrm{CH}_{4}$ emission. Anaerobic $\mathrm{CH}_{4}$ oxidation occurs in ecosystems other than paddy soils ${ }^{3,60)}$. Although there have been no reports of the isolation of bacteria that affect anaerobic $\mathrm{CH}_{4}$ oxidation ${ }^{74}$, the possibility of anaerobic $\mathrm{CH}_{4}$ oxidation in paddy fields has been suggested by Miura et al. ${ }^{94)}$ and Murase and Kimura ${ }^{99)}$.

Amann et $a l .{ }^{4)}$ reported that probably less than $1 \%$ of bacterial species have ever been isolated. The microorganisms that have been isolated are not necessarily those that are the only, or the most active, ones in the soil ${ }^{76)}$. As suggested by Kumaraswamy et $a .^{74)}$ and Schimel ${ }^{116)}$, further microbial studies will enable us to predict ecosystem behavior and the ecological significance of diversity and community structure.

\section{Conclusions}

This paper reviewed the effect of field management on the emission of $\mathrm{CH}_{4}$ on a field scale, which is the basis used for rice production by farmers. The most important objective of studies on $\mathrm{CH}_{4}$ emission from paddy fields is the mitigation of global warming. Methane emission is controlled by factors on various scales, and there is no sole solution to the balancing of rice production with $\mathrm{CH}_{4}$ emission and global warming. In a transient situation, we can establish winwin options to both sustain rice yield and mitigate $\mathrm{CH}_{4}$ emission, e.g. water management and nitrogen fertilizer application. Combination, ramification, and specialization of field management replying to the demand on site will urge to study GHG emissions from paddy fields. Further studies to unravel such phenomena, especially on a microbial scale, will offer us knowledge that can be used to solve the problem on a large scale.

\section{References}

1) Adachi, K. 2001. Methanogenic Archaea and methanotrophic bacteria in a subtropical paddy field and their interaction: Controlling methane emissions from paddy fields. Microbes Environ. 16: 197-205.

2) Agnihotri, S., K. Kulshershtha and S.N. Singh. 1999. Mitigation strategy to contain methane emission from rice-fields. Environ. Monit. Assess. 58: 95-104.

3) Alperin, M.J. and W.S. Reeburg. 1985. Inhibition experiments on anaerobic methane oxidation. Appl. Environ. Microbiol. 50: 940-945.

4) Amann, R.I., W. Ludwig and K.H. Schleifer. 1995. Phylogenetic identification and in situ detection of individual microbial cells without cultivation. Microbiol. Rev. 59: 143-169.

5) Asakawa, S. and K. Hayano. 1995. Populations of methanogenic bacteria in paddy field soil under double cropping conditions 
(Rice-Wheat). Biol. Fertil. Soils 20: 113-117.

6) Asakawa, S., H. Morii, M. Akagawa-Matsushita, Y. Koga and K. Hayano. 1993. Characterization of Methanobrevibacter arboriphilicus SA isolated from a paddy field soil and DNA-DNA hybridization among M. arboriphilicus strains. Int. J. Syst. Bacteriol. 43: 683-686.

7) Aselman, I. and P.J. Crutzen. 1989. The global distribution of natural freshwater wetlands and rice paddies, their net primary productivity, seasonality and possible methane emission. J. Atmos. Chem. 8: 307-358.

8) Aulakh, M.S., R. Wassmann, C. Bueno and H. Rennenberg. 2001. Impact of root exudates of different cultivars and plant development stages of rice (Oryza sativa L.) on methane production in a paddy soil. Plant Soil 230: 77-86.

9) Banik, A., M. Sen and S.P. Sen. 1996. Effects of inorganic fertilizers and micronutrients on methane production from wetland rice (Oryza sativa L.). Biol. Fertil. Soils 21: 319-322.

10) Bender, M. and R. Conrad. 1992. Kinetics of $\mathrm{CH}_{4}$ oxidation in oxic soils exposed to ambient air or high $\mathrm{CH}_{4}$ mixing ratios. FEMS Microbiol. Ecol. 101: 261-270.

11) Bharati, K., S.R. Mohanty, D.P. Singh, V.R. Rao and T.K. Adhya. 2000. Influence of incorporation or dual cropping of Azolla on methane emission from a flooded alluvial soil planted to rice in eastern India. Agric. Ecosyst. Environ. 79: 73-83.

12) Bodelier, P.L.E., A.P. Hahn, I.R. Arth and P. Frenzel. 2000. Effects of ammonium-based fertilization on microbial processes involved in methane emission from soils planted with rice. Biogeochemistry 51: 225-257.

13) Bodelier, P.L.E., P. Roslev, T. Henckel and P. Frenzel. 2000 Stimulation by ammonium-based fertilizers of methane oxidation in soil around rice roots. Nature 403: 421-424.

14) Bossio, D.A., W.R. Horwath, R.G. Mutters and C. van Kessel. 1999. Methane pool and flux dynamics in a rice field following straw incorporation. Soil Biol. Biochem. 31: 1313-1322.

15) Bowman, J.P., L. Jimenez, I. Rosario, T.C. Hazen and G.S. Sayler. 1993. Characterization of the methanotrophic bacterial community present in a trichloroethylene-contaminated subsurface groundwater site. Appl. Environ. Microbiol. 59: 23802387.

16) Bronson, K.F., H.U. Neue, U. Singh and E.B. Abao Jr. 1997. Automated chamber measurements of methane and nitrous oxide flux in a flooded rice soil: I. Residue, nitrogen, and water management. Soil Sci. Soc. Am. J. 61: 981-987.

17) Butterbach-Bahl, K., H. Papen and H. Rennenberg. 1997. Impact of gas transport through rice cultivars on methane emission from paddy fields. Plant Cell Environ. 20: 1175-1183.

18) Cai, Z.C. 1997. A category for estimate of $\mathrm{CH}_{4}$ emission from rice paddy fields in China. Nutr. Cycling Agroecosyst. 49: 171179.

19) Cai, Z.C., G. Xing, X. Yan, H. Xu, H. Tsuruta, K. Yagi and K. Minami. 1997. Methane and nitrous oxide emissions from paddy fields as affected by nitrogen fertilizers and water management. Plant Soil 196: 7-14.

20) Cai, Z.C. and A.R. Mosier. 2000. Effect of $\mathrm{NH}_{4} \mathrm{Cl}$ addition on methane oxidation by paddy soils. Soil Biol. Biochem. 32: $1537-1545$.

21) Cao, M., K. Gregson and S. Marshall. 1998. Global methane emission from wetlands and its sensitivity to climate change. Atmos. Environ. 32: 3293-3299.

22) Chanton, J.P., G.J. Whiting, N.E. Blair, C.W. Lindau and P.K.
Bollich. 1997. Methane emission from rice: Stable isotopes, diurnal variations, and $\mathrm{CO}_{2}$ exchange. Global Biogeochem. Cycles 11: 15-27.

23) Chareonsilp, N., C. Buddhaboon, P. Promnart, R. Wassmann and R.S. Lantin. 2000. Methane emission from deepwater rice fields in Thailand. Nutr. Cycling Agroecosyst. 58: 339-347.

24) Chidthaisong, A., H. Obata and I. Watanabe. 1999. Methane formation and substrate utilization in anaerobic rice soils as affected by fertilisation. Soil Biol. Biochem. 31: 135-143.

25) Cicerone, R.J. and R.S. Oremland. 1988. Biogeochemical aspects of atmospheric methane. Global Biogeochem. Cycles 2: 299-327.

26) Cole, C.V., J. Duxbury, J. Freney, O. Heinemeyer, K. Minami, A.R. Mosier, K. Paustian, N. Rosenberg, N. Sampson, D. Sauerbeck and Q. Zhao. 1997. Global estimates of potential mitigation of greenhouse gas emissions by agriculture. Nutr. Cycling Agroecosyst. 49: 221-228.

27) Conrad, R. 1996. Soil microorganisms as controllers of atmospheric trace gases $\left(\mathrm{H}_{2}, \mathrm{CO}, \mathrm{CH}_{4}, \mathrm{OCS}, \mathrm{N}_{2} \mathrm{O}\right.$, and $\left.\mathrm{NO}\right)$. Microbiol. Rev. 60: 609-640.

27a) Conrad, R. and F. Rothfuss. 1991. Methane oxidation in the soil surface layer of a flooded rice field and the effect of ammonium. Biol. Fertil. Soils 12: 28-32.

28) Dannenberg, S. and R. Conrad. 1999. Effect of rice plants on methane production and rhizospheric metabolism in paddy soil. Biogeochemistry 45: 53-71.

29) Delwiche, C.C. and R.J. Cicerone. 1993. Factors affecting methane production under rice. Global Biogeochem. Cycles. 7: 143155.

30) Denier van der Gon, H.A.C. and H.U. Neue. 1994. Impact of gypsum application on the methane emission from a wetland rice field. Global Biogeochem. Cycles 8: 127-134.

31) Dubey, S.K. 2003. Spatio-kinetic variation of methane oxidizing bacteria in paddy soil at mid-tillering: Effect of $\mathrm{N}$-fertilizers. Nutr. Cycling Agroecosyst. 65: 53-59.

32) Duiker, S.W. and R. Lal. 1999. Crop residue and tillage effects on carbon sequestration in a Luvisol in central Ohio, Soil Till. Res. 52: 73-81.

33) Dunfield, P., R. Knowles, R. Dumont and T.R. Moore. 1993. Methane production and consumption in temperature and subarctic peat soils: Response to temperature and $\mathrm{pH}$. Soil Biol. Biochem. 25: 321-326.

34) Eller, G. and P. Frenzel. 2001. Changes in activity and community structure of methane-oxidizing bacteria over the growth period of rice. Appl. Environ. Microbiol. 67: 2395-2403.

35) FAO 2005. FAOSTAT: Agriculture. URL: http://apps.fao.org/ default.htm (last updated February 2005).

36) Fetzer, S., F. Bak and R. Conrad. 1993. Sensitivity of methanogenic bacteria from paddy soil to oxygen and desiccation. FEMS Microbiol. Ecol. 12: 107-115.

37) Fey, A. and R. Conrad. 2003. Effect of temperature on the rate limiting step in the methanogenic degradation pathway in rice field soil. Soil Biol. Biochem. 35: 1-8.

38) Fung, I., J. John, J. Lerner, E. Matthews, M. Prather, L.P. Steele and P.J. Fraser. 1991. Three-dimension model synthesis of the global methane cycle. J. Geophys. Res. 96: 13033-13065.

39) Furukawa, Y., T. Tsuji and K. Inubushi. 2001. Suppression of methane emission from paddy soil by application of iron materials. Jpn. J. Soil Sci. Plant Nutr. 72: 257-264 (in Japanese with English abstract). 
40) Gao, S., K.K. Tanji, S.C. Scardaci and A.T. Chow. 2002. Comparison of redox indicators in a paddy soil during rice-growing season. Soil Sci. Soc. Am. J. 66: 805-817.

41) Garcia, J.L., B.K.C. Patel and B. Ollivier. 2000. Taxonomic, phylogenetic, and ecological diversity of methanogenic Archaea. Anaerobe 6: 205-226.

42) Gilbert, B. and P. Frenzel. 1995. Methanotrophic bacteria in the rhizosphere of rice microcosms and their effect on porewater methane concentration and methane emission. Biol. Fert. Soils 20: $93-100$.

43) Goto, E., Y. Miyamori, S. Hasegawa and O. Inatsu. 2004. Reduction effects of accelerating rice straw decomposition and water management on methane emission from paddy fields in a cold distinct. Jpn. J. Soil Sci. Plant Nutr. 75: 191-201 (in Japanese with English abstract).

44) Hadi, A., M. Haridi, K. Inubushi, E. Purnomo, F. Razie and H. Tsuruta. 2001. Effect of land-use change in tropical peat soil on the microbial population and emission of greenhouse gases. Microbes Environ. 16: 79-86.

45) Halvorson, A.D., B.J. Wienhold and A.L. Black. 2002. Tillage, nitrogen, and cropping system effects on soil carbon sequestration. Soil Sci. Soc. Am. J. 66: 906-912.

46) Hanaki, M., T. Ito and M. Saigusa. 2002. Effect of no-tillage rice (Oryza sativa L.) cultivation on methane emission in three paddy fields of different soil types with rice straw application. Jpn. J. Soil Sci. Plant Nutr. 73: 135-143 (in Japanese with English abstract).

47) Harada, N., S. Otsuka, M. Nishimura and S. Matsumoto. 2005. Influences of indigenous phototrophs on methane emissions from a straw-amended paddy soil. Biol. Fertil. Soils 41: 46-51.

48) Hattori, C., A. Ueki, T. Seto and K. Ueki. 2001. Seasonal variations in temperature dependence of methane production in paddy soil. Microb. Environ. 16: 227-233.

49) Hein, R., P.J. Crutzen and M. Heinmann. 1997. An inverse modeling approach to investigate the global atmospheric methane cycle. Global Biogeochem. Cycles 11: 43-76.

50) Holzapfel-Pschorn, A. and W. Seiler. 1986. Methane emission during cultivation period from an Italian rice paddy. J. Geophys. Res. 91: 11803-11814.

51) Hori, K., K. Inubushi, S. Matsumoto and H. Wada. 1990. Competition for acetic acid between methane formation and sulfate reduction in the paddy soil. Jpn. J. Soil Sci. Plant Nutr. 61: 572578 (in Japanese with English abstract).

52) Hori, K., K. Inubushi, S. Matsumoto and H. Wada. 1993. Competition for hydrogen between methane formation and sulfate reduction in a paddy soil. Jpn. J. Soil Sci. Plant Nutr. 64: 363-367 (in Japanese with English abstract).

53) Houweling, S., T. Kaminski, F. Dentener, J. Lelieveld and M. Heimann. 1999. Inverse modeling of methane sources and sinks using the adjoint of a global transport model. J. Geophys. Res. 104: $26137-26160$.

54) Hua, X., G. Xing, Z.C. Cai and H. Tsuruta. 1997. Nitrous oxide emissions from three rice paddy fields in China. Nutr. Cycling Agroecosyst. 49: 23-28.

55) Inubushi, K., Y. Muramatsu and M. Umebayashi. 1994. Effect of incorporation-timing of rice straw on methane emission from paddy soil. Jpn. J. Soil Sci. Plant Nutr. 65: 22-26 (in Japanese with English abstract).

56) IPCC 1996. Climate change 1995: Scientific-technical analyses. Cambridge University Press, Cambridge.
57) IPCC 2001. Climate change 2001: The scientific basis. Cambridge University Press, Cambridge.

58) IRRI 2005. World rice statistics. URL: http://www.irri.org/science/ricestat/ (last updated May 2005)

59) Ishibashi, E., N. Akai, M. Ohya, T. Ishii and H. Tsuruta. 2001. The influence of no-tilled direct seeding cultivation on methane emission from three rice paddy fields in Okayama, western Japan: 2. The relationship between the continuation of no-tilled cultivation and methane emission. Jpn. J. Soil Sci. Plant Nutr. 72: 542-549 (in Japanese with English abstract).

60) Iversen, N. 1996. Methane oxidation in coastal marine environments, p. 35-68. In J.C. Murrell and D.P. Kelly (eds.), Microbiology of atmospheric trace gases: sources, sinks and global change processes, Springer, Berlin.

61) Jäckel, U., S. Russo and S. Schnell. 2005. Enhanced iron reduction by iron supplement: A strategy to reduce methane emission from paddies. Soil Biol. Biochem. 37: 2150-2154.

62) Jermsawatdipong, P., J. Murase, P. Prabuddham, Y. Hasathon, N. Khomthong, K. Naklang, A. Watanabe, H. Haraguchi and M. Kimura. 1994. Methane emission from plots with differences in fertilizer application in Thai paddy fields. Soil Sci. Plant Nutr. 40: $63-71$.

63) Joulian, C., S. Escoffier, J. Le Mer, H.U. Neue and P.A. Roger. 1997. Populations and potential activities of methanogens and methanotrophs in ricefields: relations with soil properties. Eur. J. Soil Biol. 33: 105-116.

64) Joulian, C., B. Ollivier, H.U. Neue and P.A. Roger. 1996. Microbiological aspects of methane emission by a ricefield soil from Camargue (France): 1. Methanogenesis and related microflora. Eur. J. Soil Biol. 32: 61-70.

65) Kanno, T., Y. Miura, H. Tsuruta and K. Minami. 1997. Methane emission from rice paddy fields in all of Japanese prefecture. Nutr. Cycling Agroecosyst. 49: 147-151.

66) Kern, J.S., Z.T. Gong, G.L. Zhang, H.Z. Zhuo and G.B. Luo. 1997. Spatial analysis of methane emissions from paddy soil in China and the potential for emissions reduction. Nutr. Cycling Agroecosyst. 49: 181-195.

67) Kesheng, S. and L. Zhen. 1997. Effect of rice cultivars and fertilizer management on methane emission in a rice paddy in Beijing. Nutr. Cycling Agroecosyst. 49: 139-146.

68) Kimura, M., J. Murase and Y. Lu. 2004. Carbon cycling in rice field ecosystems in the context of input, decomposition and translocation of organic materials and the fates of their end products $\left(\mathrm{CO}_{2}\right.$ and $\left.\mathrm{CH}_{4}\right)$. Soil Biol. Biochem. 36: 1399-1416.

69) Klüber, H.D. and R. Conrad. 1998. Effect of nitrate, nitrite, NO and $\mathrm{N}_{2} \mathrm{O}$ on methanogenesis and other redox processes in anoxic rice field soil. FEMS Microbiol. Ecol. 25: 301-318.

70) Ko, J.Y. and H.W. Kang. 2000. The effect of cultural practices on methane emission from rice fields. Nutr. Cycling Agroecosyst. 58: 311-314.

71) Kudo, Y., T. Nakajima, T. Miyaki and H. Oyaizu. 1997. Methanogen flora of paddy soils in Japan. FEMS Microbiol. Ecol. 22: $39-48$.

72) Kumagai, K. and Y. Konno. 1998. Methane emission from rice paddy fields after upland farming. Jpn. J. Soil Sci. Plant Nutr. 69: 333-339 (in Japanese with English abstract).

73) Kumaraswamy, S., B. Ramakrishnan, S.N. Satpathy, A.K. Rath, S. Misra, V.R. Rao and N. Sethunathan. 1997. Spatial distribution of methane-oxidizing activity in a flooded rice soil. Plant Soil 191: 241-248. 
74) Kumaraswamy, S., A.K. Rath, B. Ramakrishnan and N. Sethunathan. 2000. Wetland rice soils as sources and sinks of methane: A review and prospects for search. Biol. Fertil. Soils 31: 449-461.

75) Lelieveld, J., P. Crutzen and F.J. Denterer. 1998. Changing concentration, lifetime and climate forcing of atmospheric methane. Tellus 50B: 128-150.

76) Le Mer, J. and P. Roger. 2001. Production, oxidation, emission and consumption of methane by soils: A review. Eur. J. Soil Biol. 37: 25-50.

77) Le Mer, J., S. Escoffier, C. Chessel and P.A. Roger. 1996. Microbiological aspects of methane emission by a ricefield soil from Camargue (France): 2. Methanotrophy and related microflora. Eur. J. Soil Biol. 32: 71-80.

78) Lindau, C.W., P.K. Bollich, R.D. Delaune, W.H. Patrick Jr. and V.J. Law. 1991. Effect of urea fertilization and environmental factors on $\mathrm{CH}_{4}$ emissions from a Louisiana, USA rice field. Plant Soil 136: 195-203.

79) Lindau, C.W. and P.K. Bollich. 1993. Methane emissions from Louisiana first and ratoon crop rice. Soil Sci. 156: 42-48.

80) Lindau, C.W., P.K. Bollich, R.D. Delaune, A.R. Mosier and K.F. Bronson. 1993. Methane mitigation in flooded Louisiana rice fields. Biol. Fertil. Soils 15: 174-178.

81) Lindau, C.W. 1994. Methane emissions from Louisiana rice fields amended with nitrogen fertilizers. Soil Biol. Biochem. 26: 353-359.

82) Liou, R.M., S.N. Huang and C.W. Lin. 2003. Methane emission from fields with differences in nitrogen fertilizers and rice varieties in Taiwan paddy soils. Chemosphere 50: 237-246.

83) Lu, Y., R. Wassmann, H.U. Neue and C. Huang. 2000. Dynamics of dissolved carbon and methane emissions in a flooded rice soil. Soil Sci. Soc. Am. J. 64: 2011-2017.

84) Masscheleyn, P.H., R.D. DeLaune and W.H. Patrick Jr. 1993. Methane and nitrous oxide emissions from laboratory measurements of rice soil suspension: Effect of soil oxidation-reduction status. Chemosphere 26: 251-260.

85) Matsumoto, J., Y. Minamiyama, S. Akahori and K. Takahashi. 2002. Suppression of methane emission from paddy field supplemented with organic matter. Jpn. J. Soil Sci. Plant Nutr. 73: 315-318 (in Japanese with English abstract).

86) Mayer, H.P. and R. Conrad. 1990. Factors influencing the population of methanogenic bacteria and the inhibition of methane production upon flooding of paddy soil. FEMS Microbiol. Lett. 73: 103-111.

87) Min, H., Y.H. Zhao, M.C. Chen and Y. Zhao. 1997. Methanogens in paddy rice soil. Nutr. Cycling Agroecosyst. 49: 163169.

88) Minamikawa, K. and N. Sakai. 2005. The effect of water management based on soil redox potential on methane emission from two kinds of paddy soils in Japan. Agric. Ecosyst. Environ. 107: 397-407.

89) Minamikawa, K., N. Sakai and H. Hayashi. 2005. A case study on the effect of urea application on the annual budget of carbon gases emission from a paddy field. Jpn. Soc. Farm Work Res. 40: $141-150$.

90) Minamikawa, K., N. Sakai and H. Hayashi. 2005. The effect of ammonium sulfate application on methane emission and soil carbon content of a paddy field in Japan. Agric. Ecosyst. Environ. 107: 371-379.

91) Minamikawa, K. and N. Sakai. 2006. The practical use of water management based on soil redox potential for decreasing methane emission from a paddy field in Japan. Agric. Ecosyst. Environ. 116: 181-188.

92) Mishra, S., A.K. Rath, T.K. Adhya, V.R. Rao and N. Sethunathan. 1997. Effect of continuous and alternate water regimes on methane efflux from rice under greenhouse conditions. Biol. Fertil. Soils 24: 399-405.

93) Mitra, S., M.C. Jain, S. Kumar, S.K. Bandyopadhyay and N. Kalra. 1999. Effect of rice cultivars on methane emission. Agric. Ecosyst. Environ. 73: 177-183.

94) Miura, Y., A. Watanabe, J. Murase and M. Kimura. 1992. Methane production and its fate in paddy fields. II. Oxidation of methane and its coupled ferric oxide reduction in subsoil. Soil Sci. Plant Nutr. 38: 673-679.

95) Miyoshi, A., T. Oshio and A. Ushio. 2000. Effect of non-tilled rice transplanting culture on methane emission from paddy fields. Kinki Chugoku Agric. Res. 100: 20-24 (in Japanese).

96) Mohanty, S.R., K. Bharati, B.T.S. Moorthy, B. Ramakrishnan, V.R. Rao, N. Sethunathan and T.K. Adhya. 2001. Effect of the herbicide butachor on methane emission and ebullition flux from a direct-seeded flooded rice field. Biol. Fertil. Soils 33: 175-180.

97) Morimura, T., H. Narioka, S. Aso, H. Takenaga and M. Yoshiba. 1995. Methane production and soil physical properties of direct seeding of paddy rice on submerged paddy fields. Jpn. J. Soil Sci. Plant Nutr. 66: 632-638 (in Japanese with English abstract).

98) Mosier, A.R., J.M. Duxbury, J.R. Freney, O. Heinemeyer, K. Minami and D.E. Johnson. 1998. Mitigating agricultural emissions of methane. Climatic Change 40: 39-80.

99) Murase, J. and M. Kimura. 1994. Methane production and its fate in paddy fields. IV. Sources of microorganisms and substrates responsible for anaerobic methane oxidation in subsoil. Soil Sci. Plant Nutr. 40: 57-61.

100) Neue, H.U., R.S. Latin, R. Wassmann, J.B. Aduna, C.R. Alberto and M.J.F. Andales. 1994. Methane emission from rice soils of the Philippines, p. 55-63. In K. Minami, A. Mosier and R. Sass (eds.), $\mathrm{CH}_{4}$ and $\mathrm{N}_{2} \mathrm{O}$ : Global emission and controls from rice fields and other agricultural and industrial sources, Natl. Inst. of Agro-Environ. Sci., Tsukuba.

101) Neue, H.U. and R.L. Sass. 1998. The budget of methane from rice fields. IGACtivities Newsletter 12: 3-11.

102) Nishimura, S., T. Sawamoto, H. Akiyama, S. Sudo and K. Yagi. 2004. Methane and nitrous oxide emissions from a paddy field with Japanese conventional water management and fertilizer application. Global Biogeochem. Cycles 18: GB2017.

103) Nozoe, T., Y. Nishibata, T. Sekiguchi and T. Inoue. 1999. Effects of the addition of Fe-containing slag fertilizers on the changes in Eh in paddy soil. Soil Sci. Plant Nutr. 45: 729-735.

104) Nugroho, S.G., J. Lumbanraja, H. Suprapto, Sunyoto, W.S. Ardjasa, H. Haraguchi and M. Kimura. 1994. Methane emission from an Indonesian paddy field subjected to several fertilizer treatments. Soil Sci. Plant Nutr. 40: 275-281.

105) Olivier, J.G.J., A.F. Bouwman, J.J.M. Berdowski, J.P.J. Bloos, A.J.H. Visschedijk, C.W.M. van der Maas and P.Y.J. Zasndveld. 1999. Sectional emission inventories of greenhouse gases for 1990 on a per country basis as well as on $1 \times 1$. Environ. Sci. Policy 2: 241-263.

106) Parashar, D.C., A.P. Mitra, S.K. Sinha, P.K. Gupta, J. Rai, R.C. Sharma, N. Singh, S. Kaul, G. Lal, A. Chaudhary, H.S. Ray, 
S.N. Das, K.M. Parida, S.B. Rao, S.P. Kanungo, T. Ramasami, B.U. Nair, M. Swamy, G. Singh, S.K. Gupta, A.R. Singh, B.K. Saikia, A.K.S. Barua, M.G. Pathak, C.P.S. Iyer, M. Gopalakrishnan, P.V. Sane, S.N. Singh, R. Banerjee, N. Sethunathan, T.K. Adhya, V.R. Rao, P. Palit, A.K. Saha, N.N. Purkait, G.S. Chaturvedi, S.P. Sen, M. Sen, B. Sarkar, A. Banik, B.H. Subbaraya, S. Lal and S. Venkatramani. 1994. Methane budget from Indian paddy fields, p. 27-39. In K. Minami, A. Mosier and R. Sass (eds.), $\mathrm{CH}_{4}$ and $\mathrm{N}_{2} \mathrm{O}$ : Global emission and controls from rice fields and other agricultural and industrial sources, Natl. Inst. of Agro-Environ. Sci., Tsukuba.

107) Qu, D., S. Ratering and S. Schnell. 2004. Microbial reduction of weakly crystalline iron (III) oxides and suppression of methanogenesis in paddy soil. Bull. Environ. Contam. Toxicol. 72: 1172-1181.

108) Rajagopal, B.S., N. Belay and L. Daniels. 1988. Isolation and characterization of methanogenic bacteria from rice paddies. FEMS Microbiol. Lett. 53: 153-158.

109) Ratering, S. and R. Conrad. 1998. Effects of short-term drainage and aeration on the production of methane in submerged rice soil. Global Change Biol. 4: 397-407.

110) Rath, A.K., B. Swain, B. Ramakrishnan, D. Panda, T.K. Adhya, V.R. Rao and N. Sethunathan. 1999. Influence of fertilizer management and water regime on methane emission from rice fields. Agric. Ecosyst. Environ. 76: 99-107.

111) Sass, R.L., F.M. Fisher, P.A. Harcombe and F.T. Turner. 1990. Methane production and emission in a Texas rice-field. Global Biogeochem. Cycles 4: 47-68.

112) Sass, R.L., F.M. Fisher and Y.B. Wang. 1992. Methane emission from rice fields: The effect of floodwater management. Global Biogeochem. Cycles 6: 249-262.

113) Sass, R.L. and F.M. Fisher. 1994. $\mathrm{CH}_{4}$ emission from paddy fields in the United States gulf coast area, p. 1-7. In K. Minami, A. Mosier and R. Sass (eds.), $\mathrm{CH}_{4}$ and $\mathrm{N}_{2} \mathrm{O}$ : Global emission and controls from rice fields and other agricultural and industrial sources, Natl. Inst. of Agro-Environ. Sci., Tsukuba.

114) Sass, R.L., F.M. Fisher Jr. and A. Ding. 1999. Exchange of methane from rice fields: National, regional, and global budgets. J. Geophys. Res. 104: 26943-26951.

115) Satpathy, S.N., A.K. Rath, S.R. Mishra, S. Kumaraswamy, B. Ramakrishnan, T.K. Adhya and N. Sethunathan. 1997. Effect of chlorocyclohexane on methane production and emission from flooded rice soil. Chemosphere 34: 2663-2671.

116) Schimel, J. 2000. Rice, microbes and methane. Nature 403: 375-376.

117) Schütz, H., W. Seiler and R. Conrad. 1989. Process involved in formation and emission of methane in rice paddies. Biogeochem. 7: 33-53.

118) Schütz, H., A. Holzapfel-Pschorn, R. Conrad, H. Rennenberg and W. Seiler. 1989. A 3-year continuous record on the influence of daytime, season and fertilizer treatment on methane emission rates from an Italian rice paddy. J. Geophys. Res. 94: 16405-16416.

119) Schütz, H., P. Schröder and H. Rennenberg. 1991. Role of plants in regulating the methane flux to the atmosphere, p. 29-63. In T.D. Sharkey, E.A. Holland and H.A. Mooney (eds.), Trace gas emissions by plants, Academic Press, San Diego.

120) Singh, S., A.K. Kashyap and J.S. Singh. 1998. Methane flux in relation to growth and phenology of a high yielding rice variety as affected by fertilization. Plant Soil 201: 157-164.
121) Takai, Y. 1970. The mechanism of reduction in waterlogged paddy soil. Folia Microbiol. 11: 304-313.

122) Takeda, K. 1988. Characteristics of a nitrogen-fixing methanotroph, Methylocystis T-1, Antonie Leeuwenhoek Int. J. G. 54: 521-523.

123) Takeda, K., S. Suzuki, K. Neko and Y. Tomiyama. 1998. Enumeration and characteristics of methanotrophs in paddy soils and rice roots. Jpn. J. Soil Sci. Plant Nutr. 69: 570-575 (in Japanese with English abstract).

124) Tsuruta, H., Y. Ozaki, Y. Nakajima and H. Akiyama. 1998. Development of LCA method in agricultural systems: Impact assessment of rice paddy fields on atmospheric and aquatic environments, p. 209-212. In proceedings on the third international conference on EcoBalance, Tsukuba (in Japanese).

125) Van den Pol-van Dasselaar, A. and O. Oenema. 1999. Methane production and carbon mineralization of size and density fractions of peat soils. Soil Biol. Biochem. 31: 877-886.

126) Wang, B., Y. Xu, Z. Wang, Z. Li, Y. Ding and Y. Guo. 1999. Methane production potentials of twenty-eight rice soils in China. Biol. Fertil. Soils 29: 74-80.

127) Wang, B., Y. Xu, Z. Wang, Z. Li, Y. Guo, K. Shao and Z. Chen. 1999. Methane emissions from ricefields as affected by organic amendment, water regime, crop establishment, and rice cultivar. Environ. Monit. Assess. 57: 213-228.

128) Wang, M.X., A. Dai, X. Shangguan, L. Ren, R. Shen, H. Schütz, W. Seiler, R.A. Rasmussen and M.A.K. Khalil. 1994. Sources of methane in China, p. 9-26. In K. Minami, A. Mosier and R. Sass (eds.), $\mathrm{CH}_{4}$ and $\mathrm{N}_{2} \mathrm{O}$ : Global emission and controls from rice fields and other agricultural and industrial sources, Natl. Inst. of Agro-Environ. Sci., Tsukuba.

129) Wang, Z., R.D. Delaune, C.W. Lindau and W.H. Patrick Jr. 1992. Methane production from anaerobic soil amended with rice straw and nitrogen fertilizers. Fert. Res. 33: 115-121.

130) Wang, Z.P., R.D. DeLaune, P.H. Masscheleyn and W.H. Patrick Jr. 1993. Soil redox and $\mathrm{pH}$ effects on methane production in a flooded rice soil. Soil Sci. Soc. Am. J. 57: 382-385.

131) Wang, Z., H. Kludze, C.R. Crozier and W.H. Patrick Jr. 1995. Soil characteristics affecting methane production and emission in flooded rice, p. 80-90. In S. Peng et al. (Eds.), Climate change and rice, Springer, Germany.

132) Wassmann, R., H.U. Neue, R.S. Lantin, L.V. Buendia and H. Rennenberg. 2000. Characterization of methane emissions from rice fields in Asia: I. Comparison among field sites in five countries. Nutr. Cycling Agroecosyst. 58: 1-12.

133) Wassmann, R., H.U. Neue, R.S. Lantin, K. Makarim, N. Chareonsilp, L.V. Buendia and H. Rennenberg. 2000. Characterization of methane emissions from rice fields in Asia: II. Differences among irrigated, rainfed, and deepwater rice. Nutr. Cycling Agroecosyst. 58: 13-22.

134) Wassmann, R., R.S. Lantin, H.U. Neue, L.V. Buendia, T.M. Corton and Y. Lu. 2000. Characterization of methane emissions from rice fields in Asia: III. Mitigation options and future research needs. Nutr. Cycling Agroecosyst. 58: 23-36.

135) Watanabe, A. and M. Kimura. 1999. Influence of chemical properties of soils on methane emission from rice paddies. Commun. Soil Sci. Plant Anal. 30: 2449-2463.

136) Watanabe, I., T. Hashimoto and A. Shimoyama. 1997. Methaneoxidizing activities and methanotrophic populations associated with wetland rice plants. Biol. Fert. Soils 24: 261-265.

137) Watanabe, A., T. Takeda and M. Kimura. 1999. Evaluation of 
origins of $\mathrm{CH}_{4}$ carbon emitted from rice paddies. J. Geophys. Res. 104: 23623-23629.

138) Watanabe, A., M. Kajiwara, S. Yoshida and M. Kimura. 2000. Effect of planting density on methane emission from a rice paddy. Environ. Sci. 13: 223-227.

139) Yagi, K. 1997. Methane emissions from paddy fields. Bull. Natl. Inst. Agro-Environ. Sci. 14: 96-210.

140) Yagi, K. 2002. Methane emissions in rice, mitigation options for, p. 814-818. In Encyclopedia of soil science, Marcel Dekker, New York

141) Yagi, K. and K. Minami. 1990. Effect of organic matter application on methane emission from some Japanese paddy fields. Soil Sci. Plant Nutr. 36: 599-610.

142) Yagi, K., H. Tsuruta, K. Minami, P. Chairoj and W. Cholitkul. 1994. Methane emission from Japanese and Thai paddy fields, p. 41-53. In K. Minami, A. Mosier and R. Sass (eds.), $\mathrm{CH}_{4}$ and $\mathrm{N}_{2} \mathrm{O}$ : Global emission and controls from rice fields and other agricultural and industrial sources, Natl. Inst. of Agro-Environ. Sci., Tsukuba.

143) Yagi, K., H. Tsuruta, K. Kanda and K. Minami. 1996. Effect of water management on methane emission from a Japanese rice paddy field: Automated methane monitoring. Global Biogeochem. Cycles 10: 255-267.

144) Yan, X., L. Du, S. Shi and G. Xing. 2000. Nitrous oxide emission from wetland rice soil as affected by the application of controlled-availability fertilizers and mid-season aeration. Biol. Fertil. Soils 32: 60-66.

145) Yan, X., T. Ohara and H. Akimoto. 2003. Development of region-specific emission factors and estimation of methane emission from rice fields in the East, Southeast and South Asian countries. Global Change Biol. 9: 237-254.

146) Yan, X., K. Yagi, H. Akiyama and H. Akimoto. 2005. Statistical analysis of the major variables controlling methane emission from rice fields. Global Change Biol. 11: 1131-1141.
147) Yang, S.S. and H.L. Chang. 1997. Effect of fertilizer application on methane emission/production in the paddy soils of Taiwan. Biol. Fertil. Soils 25: 245-251.

148) Yang, S.S. and H.L. Chang. 2001. Methane emission from paddy fields in Taiwan. Biol. Fertil. Soils 33: 157-165.

149) Yao, H. and Z.L. Chen. 1994. Effect of chemical fertilizer on methane emission from rice paddies. J. Geophys. Res. 99: 16463-16470.

150) Yao, H. and Y.H. Zhuang. 1996. Estimation of methane emission from rice paddies in mainland China. Global Biogeochem. Cycles 10: 641-649.

151) Yao, H., R. Conrad, R. Wassmann and H.U. Neue. 1999. Effect of soil characteristics on sequential reduction and methane production in sixteen rice paddy soils from China, the Philippines, and Italy. Biogeochemistry 47: 269-295.

152) Yao, H. and R. Conrad. 2000. Electron balance during steadystate production of $\mathrm{CH}_{4}$ and $\mathrm{CO}_{2}$ in anoxic rice soil. Eur. J. Soil Sci. 51: 369-378.

153) Yao, H. and R. Conrad. 2000. Effect of temperature on reduction of iron and production of carbon dioxide and methane in anoxic wetland rice soils. Biol. Fertil. Soils 32: 135-141.

154) Yao, H., K. Yagi and I. Nouchi. 2000. Importance of physical plant properties on methane transport through several rice cultivars. Plant Soil 222: 83-93.

155) Yoshiba, M., T. Morimura, S. Aso and H. Takenaga. 1996. Methane production and control in submerged soil applied with $\mathrm{Mn}^{4+}, \mathrm{Fe}^{3+}$ and $\mathrm{SO}_{4}{ }^{2-}$ rich materials. Jpn. J. Soil Sci. Plant Nutr. 67: 362-370 (in Japanese with English abstract).

156) Zou, J., Y. Huang, J. Jiang, X. Zheng and R.L. Sass. 2005. A 3year field measurement of methane and nitrous oxide emissions from rice paddies in China: Effects of water regime, crop residue, and fertilizer application. Global Biogeochem. Cycles 19: GB2021. 